\title{
Transcatheter aortic valve implantation experience at the University Hospital Centre Zagreb and University Hospital Centre Rijeka
}

\author{
Joško Bulum*, \\ Vjekoslav Tomulić ${ }^{2}$, \\ Maja Strozzi', \\ David Gobić ${ }^{2}$, \\ Ivica Šafradin', \\ Igor Medved², \\ Jadranka Šeparović \\ Hanževački', \\ Višnja Ivančan', \\ Zvonimir Ostojić' \\ 'University of Zagreb School of \\ Medicine, University Hospital \\ Centre Zagreb, Zagreb, Croatia \\ ${ }^{2}$ University of Rijeka School of \\ Medicine, University Hospital \\ Centre Rijeka, Rijeka, Croatia
}

RECEIVED:

February 9, 2016

ACCEPTED:

February 20, 2016

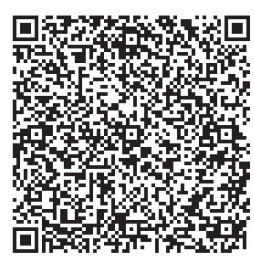

KEYWORDS: aortic stenosis, transcatheter aortic valve implantation, complications. CITATION: Cardiol Croat. 2016;11(3-4):131. | DoI: http://dx.doi.org/10.15836/ccar2016.131

*ADDRESS FOR CORRESPONDENCE: Joško Bulum, Klinički bolnički centar Zagreb, Kišpatićeva 12 , HR-10000 Zagreb, Croatia. / Phone: +385-98-171-4090 / E-mail: jbulum@gmail.com

ORCID: Joško Bulum, http://orcid.org/0000-0002-1482-6503 • Vjekoslav Tomulić, http://orcid.org/0000-0002-3749-5559 Maja Strozzi, http://orcid.org/0000-0003-4596-8261 • David Gobić, http://orcid.org/0000-0001-9406-1127 Ivica Šafradin, http://orcid.org/0000-0003-4519-5940 • Igor Medved, http://orcid.org/0000-0002-5847-2698 Jadranka Šeparović Hanževački, http://orcid.org/0000-0002-3437-6407 • Višnja Ivančan, http://orcid.org/0000-0002-7282-9753 Zvonimir Ostojić, http://orcid.org/0000-0003-1762-9270

IIIIIIIIIIIIIIIIIIIIIIIIIIIIIIIIIIIIIIIIIIIIIIIIIIIIIIIIIIIIIIIIIIIIIIIIIIIIIIIIIIIIIIIIIIIIIIIIIIIIIIIIIIIIIIIIIIIIIIIII

Transcatheter aortic valve implantation (TAVI) has been shown to be adequate modality for treatment of high risk or inoperable patients with severe symptomatic aortic stenosis. In this abstract data concerning TAVI from 2 Croatian University Hospital Centers Zagreb and Rijeka are presented.

In total 51 TAVI were preformed in these institutions (29 UHC Zagreb vs. 22 UHC Rijeka). All decisions regarding performing TAVI instead surgical aortic valve replacement (SAVR) were made by "heart team". Of all patients, 30 (58.8\%) were female and overall average age was 79.94 years. Mean European System for Cardiac Operative Risk Evaluation (EuroSCORE) was 9.95 and Society of Thoracic Surgeons (STS) mortality score 5.29. Average maximal gradient across valve before TAVI was $92 \mathrm{mmHg}$ with average aortic valve area $0.65 \mathrm{~cm}^{2} .40 \%$ of patient had coronary artery disease and all of those were treated either with coronary artery bypass graft surgery or percutaneous coronary intervention prior to TAVI. In two patients (3.92\%) valve-in-valve procedure was done. Almost all possible approaches were used (transapical, trans -carotid, -subclavian, direct aortic) but majority of procedures were performed using transfemoral approach (88\%), from which 51.9\% were done using surgical closure of femoral artery, while in rest of the cases Proscar was used. Valve was successfully implanted in $96 \%$ of cases. In one patient TAVI had to be converted in rescue SAVR. In 6 cases (11.76\%) procedure was complicated with femoral artery bleeding and in one case (1.96\%) with retroperitoneal bleeding. After the procedure 6 patients (11.76\%) developed atrioventricular block requiring permanent pacemaker implantation. Two patients (3.92\%) developed stroke and one (1.96\%) developed myocardial infarction. Overall in hospital mortality was $5.88 \%$, and one-year mortality was $4.17 \%$.

When compared to data in larger registries ${ }^{1}$ our results are almost the same and in some cases even better. In conclusion TAVI is adequate treatment option for selected patient in Croatia and we strongly encourage performing it even more in the future.

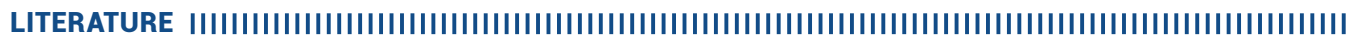

1. Holmes DR Jr, Brennan JM, Rumsfeld JS, Dai D, O'Brien SM, Vemulapalli S, et al; STS/ACC TVT Registry. Clinical outcomes at 1 year following transcatheter aortic valve replacement. JAMA. 2015;313(10):1019-28. DOI: http://dx.doi.org/10.1001/jama.2015.1474 